\title{
Adoption of Agro-forestry Patterns and Crop Systems Around Register 19 Forest Park, Lampung Province, Indonesia
}

\author{
Christine Wulandari $^{1^{*}}$, Pitojo Budiono ${ }^{2}$, Slamet Budi Yuwono ${ }^{1}$, Susni Herwanti ${ }^{1}$
}

${ }^{1}$ Forestry Department, Faculty of Agriculture, Lampung University, Jl. S. Brojonegoro 1, Bandar Lampung, Indonesia 35145

${ }^{2}$ Governance Department, Faculty of Social and Politic Science, Lampung University, Jl. S. Brojonegoro 1, Bandar Lampung, Indonesia 35145

Received May 13, 2014/Accepted July 25, 2014

\begin{abstract}
To return the ecological function of Wan Abdul Rachman Forest Park, it must be involved the role of buffer zone communities living around the forest by optimizing the cultivated land with applying agro-forestry based on socioeconomic conditions in the community, such as community preferences and adoption of agro-forestry patterns. Under these conditions it is necessary to hold a study concerning to the level of community preference to the type of plants and the level of adoption, as well as the NPV analysis of the 3 patterns of agro-forestry which are applied by the majority of community around the forest park. Results of the study revealed that there were 3 dominant plant types preferred by the community in the forest park, namely: coffee (30.8\%), cacao (35.8\%), and rubber (17.4\%). Based on these crops, there were 3 agro-forestry patterns practiced by the majority of community in their cultivated land. They were: (1) coffee-cacao-wooden plants, and fruits (47\%), (2) rubber-coffee-wooden plants, and fruit (35\%), and (3) rubber-cacao-wooden plants, and fruit (18\%). The highest personal and social NPVs obtained in the agro-forestry pattern of rubber-coffee-wooded plants, and fruits were IDR4.589.627.36 and IDR6.454.806.01, respectively. To ensure the sustainability of the program, the development of communities living around the forest together with a program of community empowerment in the block of utilization and social forestry in the forest park are recommended to continue, based on the Regional Regulation (PerDa) Number. 3/2012.
\end{abstract}

Keywords: agro-forestry, preference, adoption, NVP

*Correspondence author; email: chs.wulandari@gmail.com, tel.: +62-8128209075

\section{Introduction}

According to the Minister of Forestry Regulation (Peraturan Menteri Kehutanan or Permenhut) Number P.10/Menhut-II/2009 on the guidelines of forest parks management plan, it is stated that the definition of forest park (taman hutan raya or tahura) is a natural preservation area which is built for the purpose of collection of plants and or animals either natural or artificial, original species and or not original species, which is used for research, science, education, support cultivation, culture, tourism, and recreation. Furthermore, the enclosure mentions the need for training and the development programs of buffer zones, increasing participation and empowerment of the communities in the sustainable management of forest parks. Thus, the development of forest park is taken for granting not to solely concentrate on the conservation of natural resources and the research and development of science. The programs that are developed should include communities in the buffer zone as the main actor or program executor to improve their welfare by maintaining the ecological functions of forest parks and to reduce the destruction rate. These programs are also applied for the sustainable forest management in Wan Abdul Rachman (WAR) Forest Park, which is located in the forest area of Register 19, Lampung Province. This forest park is appointed as program implementation area by the government based on the Minister of Forestry Decree Number 408/KPTS-II/93 on August 10, 1993, which contains about the function changes and designation of protected forest areas of Gunung Betung (Register 19) covering an area of 22,244 ha and the determination as forest park.

According to Yuwono (2011) and Wulandari et al. (2013), $43 \%$ areas of WAR Forest Park have suffered damage accompanied with the high increase in annual surface runoff coefficient (C), from $48.6 \%$ (in 1991-1995) to $61.6 \%$ (in 2002-2006) which was worsen by debit fluctuation that was higher than 30. Further Yuwono (2011) and Wulandari et al. (2013) stated that the increase in the debit fluctuation was due to the increase of mixed farms areas from $48.6 \%$ (in 1991) to $52.2 \%$ (in 2006), also the decrease in forest cover from $16.7 \%$ (in 1991) to $7.2 \%$ (in 2006) (Table 1). This is reasonable since WAR Forest Park gets pressure on land function from encroachers and local peoples. This area is surrounded by 5 
subdistricts that have 35 villages and are directly adjacent to the forest areas. Population density surrounding the WAR Forest Park area is relatively high. The main livelihoods of people are agriculture $(57.3 \%)$, followed by labour $(35.8 \%)$ and others (6.9\%) (Yuwono 2011). Thus, there are challenges that must be answered by the manager of WAR Forest Park to reduce the rate of deforestation by empowering local community resources and forest resources.

According to Guariguata et al. (2012), the role of all stakeholders including the local community is very important in supporting conservation efforts to reduce the rate of natural resource and forest resource degradations in sustainable manner through the planning of the program. Guariguata et al. (2012) also recommended a special training and education for stakeholders in order to better appreciate the ecological values of the forest. This is in line with the opinion of Rajati et al. (2006) which emphasizes the importance of environmental and socio-economic aspects including the role of the community in the optimization of land use. It means that the community participation is an important aspect in a sustainable land management.

In terms of human resource potential, the existence of forest farmer groups called KPPH (kelompok pengelola dan pelestari hutan or manager and conserver forest groups) which was established in 1997 supports the forest conservation efforts at the study site (Wulandari 2012). Forest farmer groups who live around the forest area of Register 19 are the first groups in Indonesia obtaining forest management license with the scheme of community forest (hutan kemasyarakatan or $\mathrm{HKm}$ ) based on the Decree Number 21/IV/PHK-2/1999 on November 13, 1999. The certificates have been awarded to $7 \mathrm{KPPHs}$ to manage the community forest area of 492.7 ha in the WAR Forest Park for 5 years with a range of agreed provision. It means that in 2004, the groups' license period was expired and then the Local Government of Lampung Province through the technical executor unit (unit pelaksana teknis or UPT) of forest park had the policy of partnership on forest management with the community as the substitution of community forestry schemes. This policy is enforcing since there has no legal framework yet that can be used in the community-based forest management on the conservation areas, including forest parks. Until now, the communities manage their forest lands in groups just like when there was community forestry program. In April 2012, the Region Regulation (Peraturan Daerah or Perda) Number 3/2012 on Collaborative Management of WAR Forest Park of Lampung Province was published, but so far the regulation could not have optimally functioned yet in supporting the communitybased forest management program.

Since carrying out HKm scheme, the community actually has applied agro-forestry in their cultivated lands either in the forest parks area or in their own land (private land). The potential of forest park resources at the research sites is the crop types according to the preferences of the community, namely coffee, cacao, and rubber as the main crops which are then combined with the wood plants, fruit trees or even with vanilla, pepper or banana. According to Wulandari (2012), agro-forestry is one of the technologies in optimizing the utilization of cultivated land with the principle of sustainability by considering the aspects of social, economic, and ecological, as well. It has been supported by Hobbs (2007) who suggests that agro-forestry is a solution to increase production of agriculture and food security because agro-forestry practice is one of conservation agriculture technology. Communities in the study sites have a preference for the types of crops which are then cropped in specific agro-forestry patterns based on their adoption toward conservation technologies introduced by the extension officers, forest park officers or from other learning outcomes such as comparative studies, or through printed media and television (Wulandari 2012).

Paul (2011) stated that economic factors also affected the preferences and adoption of the community in applying agroforestry on their cultivated land. In addition, Iskandar (2012) argued that adoption of agroforestry technology was affected by the aspects of social, economic, and ecological of the region. Under these conditions, this study performed the calculations of nett present value (NPV) of the individual and social towards agro-forestry cropping pattern adopted by the community. Thus the study will revealed the advantages of each agro-forestry pattern applied by the community in their cultivated land.

This research is important to be conducted because there are a lot of water sources in the forest park which are channeled through (PDAM) Local Government's Enterprise of Drinking Water for the citizen of Bandar Lampung, the capital city of Lampung Province. It is known that at present,

Table 1 Landuse development of Way Betung Watershed year 1990-2007 (Yuwono 2011)

\begin{tabular}{|c|c|c|c|c|c|c|c|c|c|c|c|c|c|c|}
\hline \multirow{2}{*}{ Landuse } & \multicolumn{4}{|c|}{$1990 / 1991$} & \multicolumn{6}{|c|}{$1999 / 2000$} & \multicolumn{4}{|c|}{$2006 / 2007$} \\
\hline & APL & Forest & Total & $\%$ & $\Delta \%$ & APL & Forest & Total & $\%$ & $\Delta \%$ & APL & Forest & (ha) & $\%$ \\
\hline Forest & 0.0 & 979.2 & 979.2 & 16.7 & -7.1 & 12.2 & 495.9 & 508.1 & 9.7 & -2.5 & 11.5 & 365.6 & 377.1 & 7.2 \\
\hline Mix garden & $1,783.9$ & 674.2 & $2,458.1$ & 48.6 & +11.7 & $1,740.2$ & $1,433.1$ & $3,173.3$ & 60.3 & -8.2 & $1,434.9$ & $1,309.4$ & $2,744.3$ & 52.2 \\
\hline Shurbs & 396.9 & 911.6 & $1,308.5$ & 24.8 & -12.7 & 188.9 & 448.2 & 637.1 & 12.1 & +9.9 & 523,7 & 632.5 & $1,156.2$ & 21.9 \\
\hline Dry agriculture & e 194.9 & 109.6 & 304.5 & 5.7 & +1.2 & 163.4 & 206.7 & 369.9 & 7.0 & -0.9 & 161.0 & 161.5 & 322.5 & 6.1 \\
\hline Others & 10.1 & 21.3 & 31.5 & 0.6 & +3.2 & 90.5 & 110.6 & 201.0 & 3.8 & +1.9 & 104.9 & 196.3 & 301.2 & 5.7 \\
\hline Total & $2,550.0$ & $2,710.0$ & $5,260.0$ & 100.0 & 0.0 & $2,549.5$ & $2,710.5$ & $5,260.0$ & 100.0 & 0.0 & $2,549.5$ & $2,710.5$ & $5,260.0$ & 100.0 \\
\hline
\end{tabular}

$\mathrm{APL}=$ Areal Penggunaan Lain $=$ land for others purpose 
the forest park is in the critical condition and has to be rehabilitated immediately. Now, there are a lot of housings around the forest park, so the preferences and adoption of the communities toward the plant types and agro-forestry pattern which applied in their cultivated land must be considered. The study was conducted to identify the preference on the type of crop and adoption in applying agro-forestry patterns in their cultivated land and compare the NPV analysis of each agro-forestry pattern applied by the community.

\section{Methods}

The study was conducted at WAR Forest Park which is land on forest area of Register 19 Gunung Betung on April to July 2013. The respondents were communities living in the village of Talangmulya, Parendoan, and Sumber Agung which are located around the WAR Forest Park. These 3 villages were chosen as the research sites because they are the nearest villages from the forest park, so the dynamics of the community's condition will affect the forest sustainability. Description of those villages was based on information in Profile of Sumber Agung Village (2010) and Wulandari et al. (2013).

Sumber Agung Village Administratively, Sumber Agung Village is located in Kemiling Subdistrict, Bandar Lampung City with an area of 498 ha. This village has population about 3,261 inhabitants with the proportion of the number of males almost equal to females, i.e. $51 \%: 49 \%$ respectively. The number of population who passed the general education is about 2,272 people. The number of productive age labor force is 1,747 people or about $54 \%$ of the total population. The population based on the livelihoods are farmers (56\%), others $(35 \%)$ which consist of employees, private workers, builders, service workers, motorcycle workers, etc, and the rest $(9 \%)$ as farm worker.

Parendoan Village Parendoan Village is administratively located in Teluk Betung Subdistrict, Bandar Lampung City with total area of 313 ha. The population living in this region is 4,854 inhabitants with almost equal proportion between males and females. The population in productive age is 2,738 people. Most of the population still receive 9 years basic education. The main livelihoods of the population are farmers $(43 \%)$, then farm worker $(20 \%)$, traders $(20 \%)$, and the rest $(17 \%)$ which consists of employees, retired officers, builders, and others.

Talang Mulya Village Talang Mulya Village is located in Padang Cermin Subdistrict with total area of 654 ha. Total population is 1,340 inhabitants with almost equal proportion between males and females. The main livelihoods of the population in Talang Mulya Village are farmers (79\%), and the rest $(21 \%)$ as farm worker and employees.

Sample selection and data collection The data exploration used in this study were structured interviews to the key informants (Sugiyono 2009). The selection of key informants considered the gender and was conducted with a purposive sampling method. It means that the key informants were chosen based on their gender, and there were $30 \%$ women in this research. Besides considering about the gender factor, the key informants were also chosen based on their age class and the economic conditions of their families. In 3 villages around the study sites there were 9,455 people (Profile of Sumber Agung Village 2010). Based on the Slovin formula (Wulandari et al. 2013), the minimum sample number was is calculated as shown in Equation [1]:

$n=\frac{\mathrm{N}}{\text { note: }}=\frac{9,455}{1+9,455(0.05)^{2}}=383.7 \approx 384$ respondence

$\mathrm{n}=$ number of sample

$\mathrm{N}=$ number of population

$\mathrm{e}=5 \%$ margin of error

The number of samples or respondents from each sites was calculated in proportion to the total population, namely 9,455 people. Thus, the number of samples per village was Talang Mulya Village with total 54 respondents, Parendoan Village with 196 respondents, and Sumber Agung Village with 134 respondents.

Data processing and analysis In the structured in-depth interview, the respondents were asked about the application of agro-forestry technologies in their cultivated land, including (1) preference of crops or trees selection which were cropped in their cultivated land, (2) adoption of the dominant cropping patterns which were applied in their cultivated land, and (3) products from each agro-forestry pattern which was applied by the respondents, both quantitatively and qualitatively. Preferences of crop types and adoption of communities cropping patterns were measured quantitatively (percentage) based on the accumulative number of respondent choices for the type of crops and the cropping patterns. According to Andayani (2007), NPV based on the cropping pattern of respondents who practiced agro-forestry technologies was computed using the formula as shown in Equation [2]

$$
\begin{array}{ll}
N P V= & {\left[\sum_{t=1}^{t=n} \frac{b^{t}-c^{t}}{(1+i)^{t}}\right]-K o} \\
\text { note: } & \\
b^{t} & =\text { annual gross benefit } \\
c^{\mathrm{t}} & =\text { annual costs } \\
(1+i)^{t}= & \text { discounting factor }\left(\mathrm{D}_{\mathrm{F}}\right) \\
t & =\text { economic life time; example, economic life time }= \\
& 10 \text { year } \\
t & =\mathrm{n}---\mathrm{t}=10 \\
t & =1 ; \text { first year program }
\end{array}
$$

This study used a research conceptual framework (Figure 1) to show the interrelationships of the above variables which were expected to have a direct and indirect impact to the sustainability of the WAR Forest Park as a forest management system.

\section{Results and Discussion}

Choice of crops Preference is shaped from a perception of a product and it can be said that preference is degree of 


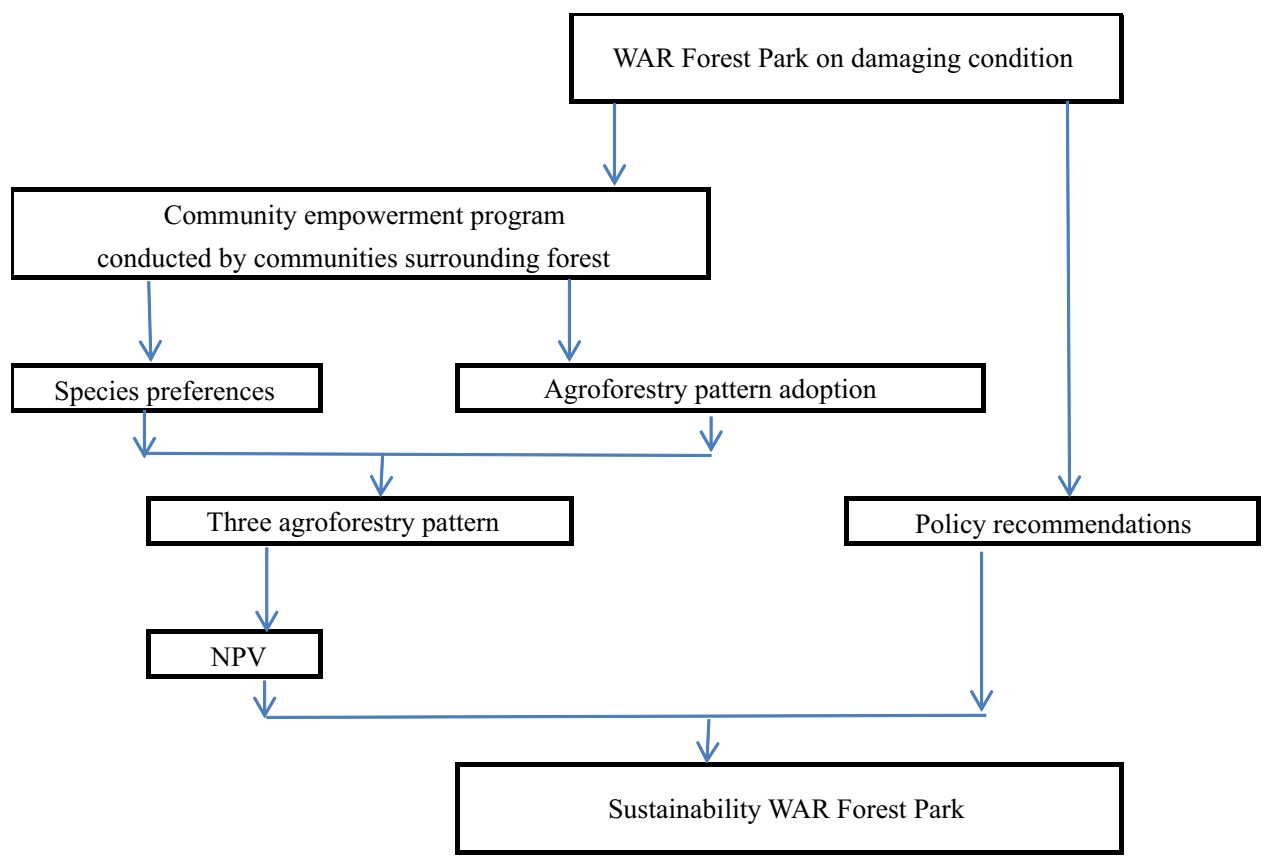

Figure 1 Research conceptual framework.

favorite, option or something which is preferred (Muzdalifah 2012). Discussing preference of the type of trees, Goibov et al. (2012) argued that farmer preferences were influenced by the socio-economic and environment factors. It was then supported by Paul (2011) who stated that preferences were also influenced by economic variables. Thus it is understandable if the results of this study indicated that the community's preference to the type of crops depends on the capital to buy the seeds (77\% of respondents) and also economic value when they sell the products later $(82 \%$ of respondents). This condition was also found from the results of the study by Andayani (2007) in Boyolali District, Central Java Province. In Madagascar, Downey and Richter (2013) found that farmer cultivation did not correspond well with planting preferences due to their economic factor consideration.

Based on the research in Register 19, (Figure 2) it is known that the community's preference in determining the type of plant grown are also determined by the factor of cultivated land ownership extents ( $73.6 \%$ respondents). In addition, this is also affected by the economic value of crops or trees (66.8\% respondents), the mastering of technology (54.3\% respondents), and the ability of economy $(41.7 \%$ respondents). The economic value and capital to buy seed are used by the farmers in determining the types of crops grown around the trees. Farmers who have an extensive land (more than $3 \mathrm{ha}$ ) have a fairly high preference towards tree planting which will bring benefits in the future. However, farmers who own relatively narrow land (less than $1 \mathrm{ha}$ ) mostly fixate on food crops that can bring the yields in a relatively short time.

Choice of agroforestry patterns In this study, the definition of technology adoption is the change of technology application by the farmers without any further intervention by the technology carrier after introducing the new technology (Murdolelono et al. 2011). It has shown that the adoption of respondents in applying an agro-forestry pattern in the research sites based on the economic values is $63 \%$, the technology mastered $(37 \%)$, and based on both economic values and technology mastered (71\%) (Figure 3). The respondents defined that the consideration of economic value in adopting the agro-forestry pattern becomes a scale of selling point from an agro forestry product if they directly sell to the consumers and exclude the calculation of the NPV values. Further Murdolelono et al. (2011) also stated that the results of some studies indicated that the technology adoption of dry land was very slow because of neglecting socio-cultural factors when the innovations were implemented at the initial step to introduce a new conservation technology. Thus, the technology adoption will be successful if it is technically feasible, economically viable, and implemented in accordance with the sociocultural conditions of local communities including preference on the type of plant or tree (Iskandar 2012). Aryono et al. (2006) added that appropriate silviculture technology is a key to be successful in agro-forestry practice.

Based on the results of Teklewold et al. (2013) in Ethiopia, it is known that community's adoption in choosing the type of crops was influenced by 8 factors, namely a household's trust in government support, credit constraints, spouse education, rainfall and plot-level disturbances, household wealth, social capital and networks, labor availability, plot, and market access. In another country in Africa, Zambia, it was founded that farmers' adoption was influenced by experiences in land tillage, farm size, and membership of organization (Nyanga 2012). In United Kingdom, the research of Lapple (2010) reported that farm size and livestock density showed a statistically significant relation to the hazard to adopt. Howley et al. (2012) added 
another significant factor to farmer adoption namely respondent characteristics which consist of family size, education, and age.

Related to the economic aspects, Jaeck and Lifran (2014) argued that farmers would adopt conservation technology or a particular cropping pattern if they would get the economic benefit from these activities. Even Steffan-Dewenter et al. (2007) said that in the field, there were farmers who change their cropping pattern that has been done to a more profitable cropping patterns.

From the results of this study, there were 19 plant types grown by the 384 respondents in their cultivated land both inside and outside of forest parks (Table 2).

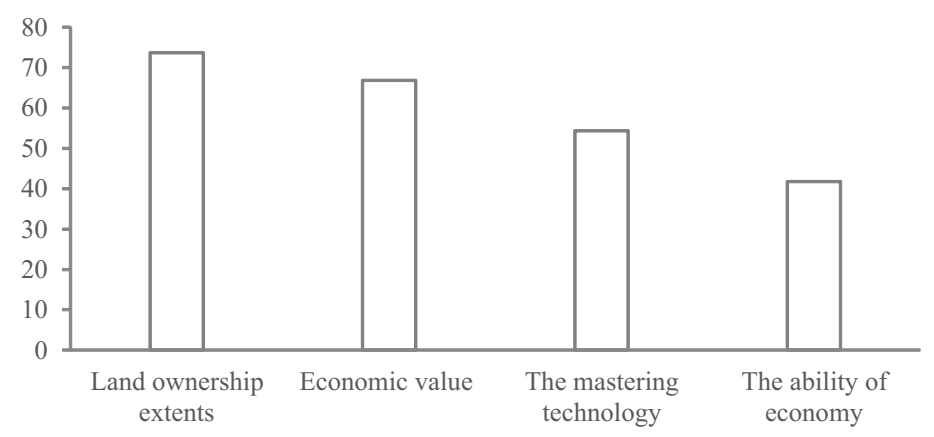

Figure 2 Factors of respondents preference to plants species.
Then, when calculating the percentage of preference, it can be seen that the percentage of respondents who have a preference choose cacao $(35.8 \%)$, followed by coffee $(30.8 \%)$, and then rubber $(17.4 \%)$. Percentage of preference in detail of 19 plant types is mentioned in Figure 4.

The results show that the respondents have already been applying agro-forestry technologies in their cultivated land (Figure 5). Main crop types of their preference could be classified into 3 cropping patterns, namely (1) coffee-cacaowood trees and fruits (47\%), (2) rubber-coffee- wood trees and fruits (35\%), and (3) rubber-cacao-wood trees and fruits $(18 \%)$. Agro-forestry pattern of coffee-cacao-wood trees and fruits means that coffee and cacao are majority plants at land

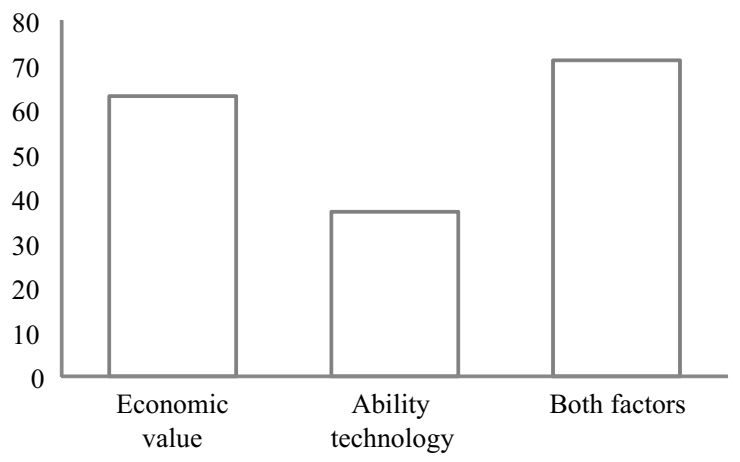

Figure 3 Factors of respondents adoption to three agroforestry patterns.

Table 2 Communities preferences on plant species

\begin{tabular}{lc}
\hline $\begin{array}{l}\text { Species } \\
\text { (local name) }\end{array}$ & Preferred by (person) \\
\hline Durian & 8 \\
Petai & 4 \\
Tangkil & 4 \\
Alpukat & 4 \\
Pala & 1 \\
Kemiri & 3 \\
Cempaka & 2 \\
Pinang & 6 \\
Kayu Manis & 1 \\
Karet & 46 \\
Bambu & 2 \\
Cengkeh & 3 \\
Aren & 1 \\
Kelapa & 2 \\
Kopi & 85 \\
Cacao & 101 \\
Pisang & 22 \\
Vanili & 1 \\
Lada & 1 \\
\hline & \\
& 2 \\
\hline
\end{tabular}




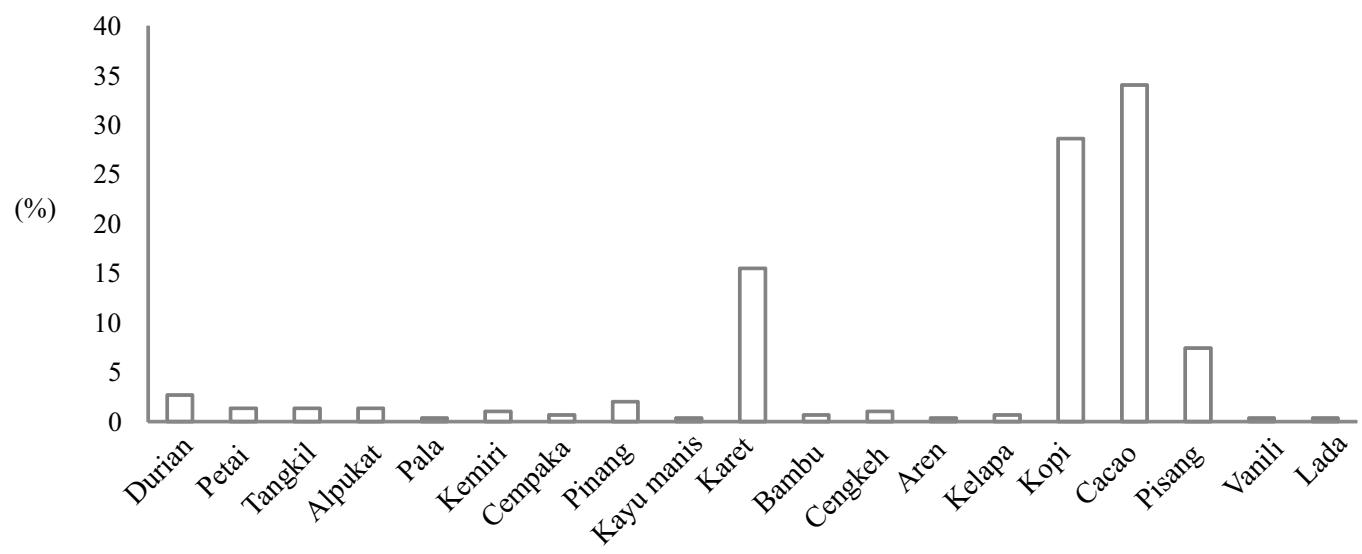

Figure 4 Communities preference on plant species (\%).

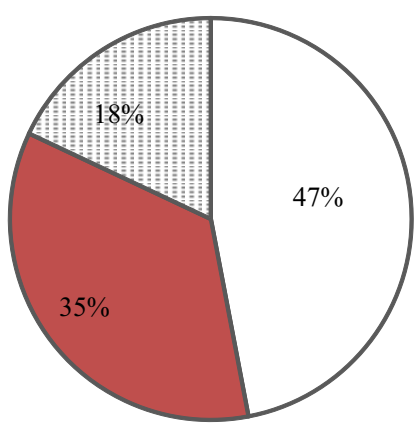

Figure 5 Three agroforestry pattern that adopted by communities. Coffee-cacao-wood trees and fruits (国), Rubber-coffee-wood trees and fruits $(\square)$. Rubber-cacao-wood trees and fruits $(\square)$.

tillage surrounding by many others wood tree and fruit species.

The respondents also said that the application of the 3 agro-forestry patterns was based on the information from the agricultural officers and the farmers from another village who said that the price of coffee, rubber, and coffee is relatively stable and easy to grow. Moreover, the respondents say that up to now, there is no information about the NPV of the plant types and the three agro-forestry patterns which have been considered to be unstable interest rate on calculation.

From the results of the study in North Lampung that the preference of selection and determination of agro-forestry pattern by the farmers is influenced by many factors which are interrelated each other, such as the mastery of technology, the wide of cultivated land, capitals, habits, courage to take risks, and knowledge (information) owned by the farmers. Farmers who adhere to the farming principle with reasonable costs would yield a highest profit over the agro-forestry production. Thus, they will not concern with the concept of biodiversity considered in managing their land, unless it can directly provide economic benefits (tangible value). According to Wulandari (2009), actually the biodiversity could be maintained when the land is managed with agro- forestry by applying the concept of segregation and integration. This concept has not yet widely known among the extension officers or the staff of forest park, because $83 \%$ of them have never known about it. It means that the sustainable land management in agro-forestry by considering biodiversity in the community's cultivated land is a challenge in supporting sustainable development around the forest parks, as one of the conservation areas.

In the results of the study in North Lampung, it was found that farmers who had an extensive cultivated land usually had the courage to take a high risk because they might try several patterns at once without feeling threatened of food security. In addition, they also had the capital to try to grow crops on the other side of their land. Farmers were also daring to take the risk if they had other income from non-agricultural sector, for example working as a civil servant or trader or from other sources.

Comparison of NPVs The invidual and social NPVs of each agro-forestry pattern were assessed and presented in Table 3. The NPV analysis was conducted in this research to determine economic value of 3 agro-forestry patterns practiced by respondents. The NPV calculations on annual crops are based on material the inputs (fertilizers, herbicides, 
Table 3 NPV Analysis on 3 agroforestry pattern that adopted by communities

\begin{tabular}{lcc}
\hline Agroforestry pattern & $\begin{array}{c}\text { NPV based on individual prices } \\
\text { IDR ha }\end{array}$ & $\begin{array}{c}\text { NPV based on social prices } \\
\text { IDR ha }^{-1}\end{array}$ \\
\hline Rubber-cacao-wood trees and fruits & $4,471,756.57$ & $6,328,042.32$ \\
Rubber-coffee-wood trees and fruits & $4,589,627.36$ & $6,454,806.01$ \\
Coffee-cacao-wood trees and fruits & $4,168,660.18$ & $6,102,684.69$ \\
\hline
\end{tabular}

etc.) and its production factors such as soil, labor, and management. Output and input values used in the NPV calculation were the discounted value of total production factors. The data were collected in July 2013 when the dollar exchange rate was around IDR11.500. Interest rate of $12 \%$ was used for the calculation of individual NPV and $8 \%$ for the social NPV.

Based on the results, it was revealed that the highest NPV is in the agro-forestry pattern of rubber-coffee-wood plants and fruit was IDR4,589,627.36 for individual NPV and IDR4,811,948.86 for social NPV. The second position was in the cropping pattern of rubber-cacao-wood plants and fruit. Whereas the lowest NPV was in the patterns of coffee-cacaowood plants and fruit with individual NPV of IDR4,168,660.18 and social NPV of IDR6,102,684.69. This is in contrary with the community's preferences on the agroforestry pattern adopted in their cultivated land where the highest preference pattern $(47 \%)$ was coffee-cacao-wood plants and fruit combination while the lowest preference pattern was rubber - cacao - wood plant and fruit (18\%). The same condition also occurs in Philippines, according to Snelder et al. (2007), the preference of farmers to the type of fruit crops in fact turned out in opposition to the results of economic calculations. While from the research of Martini et al. (2012) in Sumatra and Sulawesi, it was shown that the financial value obtained by farmers from patchouli plant in agro-forestry was only one-third of their expectations.

According to Martini et al. (2012), the conditions found in the forest park of Register 19 indicates that there is a needed program on knowledge improving and practical development of the farmers. This program should be carried out periodically for the various agro-forestry developed commodities in order to improve the welfare of the community living around the forest park. Andayani (2007) stated that the programs were also needed to increase the bargaining power of the farmers through strengthening of existing farmer' organization. These programs could be recommended to be developed in WAR Forest Park because according to Regional Regulation Number 3/2012 article 13, there is a utilization block that can be managed for ecotourism development and environmental services including traditional land tillage benefiting by local communities. In addition, the Article 15 also states that in forest park, there is a block of social forestry and rehabilitation which is aimed for the development of forests in order to improve the welfare of the community around the forests. The existence of regulations as a policy- umbrella on implementation will guarantee sustainability of the program, although in some countries it is found that the farmers ask for incentives when they are ordered to participate in natural resource development program (Ruto \& Garrod 2009).

\section{Conclusion}

The preferences of the respondents in the research sites in applying the 3 agro-forestry patterns have to consider the following factors namely cultivated and ownership areas, economic values from the plant types, the availability of funds to buy seeds, and the technology mastered. From the results, it was revealed that the community's adoption was reflected from the 3 patterns of agro-forestry which were applied on their cultivated land, namely coffee-cacao-wood plants and fruit (47\% of respondents), rubber-coffee-wood plants and fruit (35\% of respondents), and rubber-cacaowood plants and fruit (18\% of respondents). The individual NPVs of each pattern are respectively IDR4,168,660.18, IDR4,589,627.36 and IDR4,471,756.57, and the social NPVs are IDR6,102,684.69, IDR6,454,806.01 and IDR6,328,042.32, respectively. Then, the community empowerment programs in the utilization blocks and social forestry blocks which can be developed intensively in order to improve the welfare of community has been recommended. These needs are recommended because the highest percentage of adoption agro-forestry pattern is not the agro-forestry pattern that has the highest NPV.

\section{References}

Andayani W. 2007. Economic analysis of farm management agroforestry system in Boyolali District. Jurnal Rimba Kalimantan 12(1):11-15.

Aryono WB, Sabarnurdin S, Suryanto P. 2006. Fallow land model in agroforestry system. Jurnal Manajemen Hutan Tropika 12(2):15-26.

Downey MG, Richter D. 2013. Farmer preferences and the production strategies of agroforestry nurseries in Southern Madagascar. Madagascar Conservation Development Journal 8(2):55-62.

Guarigata MR, Sist P, Nasi R. 2012. Multiple use management of tropical production forests: how can we move from concept to reality? Forest Ecology and Management Journal 268:1-5. http://dx.doi.org/10.1016 /j.foreco.2011.12.047.

Goibov M, Schmitz PP, Bover S, Ahmed MN. 2012. Application of choice experiment to estimate farmers preferences for different land use in Nothern Tajikistan. Sustainable Development Journal 5(5):2-16.

Hobbs PR. 2007. Conservation agriculture: what is and why is it important for future sustainable food production. Journal of Agriculture Science 145(2):127-137. http://dx.doi.org/10.1017/S0021859607006892. 
Howley P, Donoghue CO, Heanue K. 2012. Factors affecting farmers'adoption of agricultural innovations: a panel data analysis of the use of artificial insenmination among dairy farmers in Ireland. Journal of Agriculture Science. 4(6):171-179.

Iskandar D. 2012. Inovasi dan difusi teknologi agroforestri untuk peningkatan pendapatan petani. In: Proceeding Seminar Nasional Agroforestri III. 29 Mei 2012.

Jaeck M, Lifran R. 2014. Farmers'preferences for production practices: a choice experiment study in the Rhone River Delta. Journal of Agriculture Economics 65:112-130. http://dx.doi.org/10.1111/1477-9552.12018.

Lappe D. 2010. Adoption and abandonment of organic farming: an empirical investigation of the Irish drystock sector. Journal of Agriculture Economics 61(3):697-714. http://dx.doi.org/10.1111/j.1477-9552.2010.00260.x.

Martini E, Tarigan J, Napitupulu H, Roshetko J. 2012. Agroforestri di Mata Petani: studi Kasus di Sumatra dan Sulawesi. In: Prosiding Seminar Nasional Agroforestri III. Yogyakarta, 29 Mei 2012.

Murdolelono B, da Silva H, Yusuf. 2011. Adopsi teknologi budidaya lorong pada lahan kering di Kawasan Oesao. Index Biologi dan Pertanian Indonesia 41(3):551-566.

Muzdalifah. 2012. Study on preference of consument to local fruits in Banjarbaru City. Jurnal Agribisnis Pedesaan 2(4):297-309.

Nyanga PH. 2012. Factors influencing adoption and area under conservation agriculture: a mixed methods approach. Journal of Sustainable Agriculture Research 1(2):27-40.

Paul C. 2011. Contribution of agroforestry activities to the financial socioeconomic and environmental sustainability of a carbon sink project in the Province of Kinshasa [thesis]. London: Centre for Development, Environmental and Policy, School of Oriental and African Studies.

Profile of Sumber Agung Village. 2010. Data Monografi Kelurahan Sumber Agung. Bandar Lampung.

Rajati T, Kusmana C, Darusman D, Saefuddin S. 2006. The optimalization of forest utilization to improve environment quality and people welfare surrounding the forest: case study in Sumedang Regency. Jurnal Manajemen Hutan Tropika 12(1):38-50.

Ruto E, Garrod G. 2009. Investigating farers preferences for the design of agri-environment schemes: a choice experiment approach. Journal of Environmental Planning and Management 52(5):631-647. http://dx.doi.org/10.1080/09640560902958172.

Sugiyono. 2009. Metode Penelitian Kuantitatif dan Kualitatifdan $R \& D$. Bandung: Alfabeta.

Snelder DJ, Klein M, Schuren SHG. 2007. Farmers preferences, uncertainties and opportunities in fruit-tree cultivation in Northeast Luzon. Agroforestry Systems Journal 71:1-17. http://dx.doi.org/10.1007/s10457-0079086-1.

Teklewold H M, Kassie, Shiferano B. 2013. Adoption of multiple sustainable agriculture practices in rural Ethiopia. Journal of Agricultural Economics. 64(3):597-623. http://dx.doi.org/10.1111/1477-9552. 12011.

Wulandari C. 2009. Karakteristik lanskap agroforestri. In: Arifin HS, Wulandari C, Pramukanto Q, Kaswanto RL, editors. Analisis Lanskap Agroforestri: Konsep, Metode, dan Pengelolaan Agroforestri Skala Lanskap dengan Studi Kasus Indonesia, Filipina, Laos, Thailand dan Vietnam. Bogor: IPB Press.

Wulandari C. 2012. Diversifikasi hasil agroforestry di sekitar hutan Sumber Jaya dan daerah aliran sungai (DAS) Way Besai. In: Zakaria WA and Abidin Z, editors. "Pengelolaan Hutan dan Daerah Aliran Sungai Berbasis Masyarakat: Pembelajaran dari Way Besai Lampung." Bandar Lampung: Kementrian Kehutanan, UNDP dan GEF. Pp 92-108.

Wulandari C, Yuwono SB, Budiono P, Herwanti S. 2013. Feasibility Study of Watershed Services in Register 19 Forest Area, Lampung Province. Research Report. Bogor: SEAMEO-BIOTROP.

Yuwono SB. 2011. Sustainable water resources development in Way Betung Watershed, Bandar Lampung City. [dissertation]. Bogor: Bogor Agricultural University. 